\title{
Artificial shelters (casitas) as habitats for juvenile spiny lobsters Panulirus argus in the Mexican Caribbean
}

\author{
Ana Minerva Arce ${ }^{1, *}$, William Aguilar-Dávila ${ }^{1}$, Eloy Sosa-Cordero ${ }^{1}$, John F. Caddy ${ }^{2}$ \\ ${ }^{1}$ El Colegio de la Frontera Sur, Unidad Chetumal Zona Ind. No. 2, Carr. Chetumal-Bacalar, CP 77050 Chetumal, \\ Quintana Roo, Mexico \\ ${ }^{2}$ Fisheries Department, FAO, Viale delle Terme di Caracalla, I-00100 Rome, Italy
}

\begin{abstract}
The cryptic and shelter-seeking behaviour of spiny lobsters Panulirus argus Latreille prompted the use of artificial shelters to examine the juvenile population structure at Cayos-Contoy, Quintana Roo, Mexico. We tested the hypothesis that habitat type had no influence on shelter occupancy. The artificial shelters used were concrete structures with a PVC frame (mini-size casitas). Macrofauna and potential predators associated with the mini-casitas were also quantified. The size of the lobsters harbored by these structures emphasized the importance of the Cayos-Contoy as a nursery habitat for $P$. argus. Differences in mini-casita occupancy by juveniles and the association between habitat and lobster size groups suggest that availability of natural habitats had an influence on casita occupancy. The periodic removal of all lobsters from the mini-casitas resulted in the vacancies being occupied mostly by a size-specific group of juveniles. Transitional (16 to $25 \mathrm{~mm}$ carapace length, CL) and postalgal (26 to $35 \mathrm{~mm} \mathrm{CL}$ ) juvenile stages recruited mainly to vegetated habitats, with larger lobsters occupying patch reef habitats. Mini-casita occupancy was dominated by transitional and post-algal early juvenile stages (41.1 and $34.6 \%$ respectively). The fact that the highest percentage of mini-casita occupancy is by transitional juvenile $P$. argus is considered to represent a 'population bottleneck' effect.
\end{abstract}

KEY WORDS: Artificial shelters · Spiny lobsters · Panulirus argus - Mexican Caribbean

\section{INTRODUCTION}

Habitat selection, resource use, and the ecological processes associated with distribution vary considerably between palinurid species (Kanciruk 1980). The larval stage of spiny lobster Panulirus argus is planktonic and inhabits the epipelagic portion of the Atlantic Ocean (Marx \& Herrnkind 1986) with the highest abundance near the coast (Alfonso \& Frías 1991). After metamorphosis, the first benthic stage of $P$. argus settles in a variety of environments, including high salinity estuaries (Witham et al. 1968), among mangrove roots, seagrass beds, along grassy undercuts, shallow bays, and reef lagoon areas (Davis 1971, Kanciruk 1980, Marx \& Herrnkind 1985). However, the highest densities of post-larvae are usually associated with red macroalgae Laurencia spp. (Marx \& Herrnkind 1985.

·E-mail: anamarce@ecosur-qroo.mx
Herrnkind \& Butler 1986). Subsequent juvenile stages have been described as ecologically 'transitional', moving from algal habitat to den dwelling (Marx \& Hermkind 1985, Childress \& Herrnkind 1994) and thereafter showing gregarious habitation (Smith \& Herrnkind 1992). This latter juvenile stage is referred to as 'post-algal' (Childress \& Herrnkind 1994, Field \& Butler 1994, Forcucci et al. 1994, Herrnkind \& Butler 1994). The reclusive behaviour and small size of early juvenile spiny lobsters make them difficult to sample (Marx \& Herrnkind 1985, Herrnkind \& Butler 1986 , Herrnkind et al. 1994, Norman et al. 1994), making post-settlement population parameters difficult to obtain (Herrnkind et al. 1994).

It has been hypothesized that crevice-dwelling species suffer from a declining number of suitable shelters as they grow (Morse et al. 1985), possibly leading to recruitment bottlenecks in some crevice-obligate marine invertebrates (Caddy 1986, Caddy \& Stamato- 
poulos 1990). Given the shelter-seeking behaviour of lobsters, many studies have utilized artificial shelters. Caddy \& Stamatopoulos (1990) suggest that an artificial crevice simulator may be used to determine 'population bottlenecks' for lobsters in nature.

Artificial shelters have been the focus of considerable research aimed at gaining an understanding of their impact on species survival and recruitment (Johnson et al. 1988, Spanier et al. 1988, Hixon \& Beets 1989, 1994, Eggleston et al. 1990, 1992, Briones et al. 1994, Mintz et al. 1994, Sosa-Cordero et al. in press) and their use as a harvesting tool (Miller 1982, Cruz \& Phillips 1994). Two types of artificial habitats are commonly used to study juvenile and subadult Panulirus argus populations in the Caribbean: concrete block structures (Davis 1985, Cruz et al. 1986, de León et al. 1991, Lozano-Alvarez et al. 1994) and reenforced concrete habitats called 'casitas' (Eggleston et al. 1990, 1992, Eggleston \& Lipcius 1992, Mintz et al. 1994). Casitas have several physical properties which make them a suitable (Miller 1982, Briones et al. 1994) and effective artificial shelter for lobsters including: shade and multiple den openings (Spanier \& Zimmer-Faust 1988); low-relief openings which exclude large piscine predators (Briones et al. 1994); entrances of much smaller diameter than the inner shelter (Eggleston et al. 1990, Spanier 1994); and suitability for future cohabitation (Zimmer-Faust \& Spanier 1987).

Casitas, however, harbor a range of benthic and demersal animals, many of them predators of spiny lobsters. Few studies have examined the importance of casitas (e.g. crevice availability) to the juvenile Panulirus argus populations in the Caribbean nursery areas, especially for early benthic lobsters (sensu Smith \& Herrnkind 1992, Childress \& Herrnkind 1994). The aim of this project was to study artificial shelter occupancy, using mini-size casitas, by the juvenile $P$. argus population in the northeastern coastal waters of the Yucatan Peninsula, Mexico. This involved a field study examining the variation of small juvenile $P$. argus abundance and recruitment to casitas between different microhabitats.

\section{METHODS AND MATERIALS}

Study area. In the Mexican Caribbean, off the northeastern coast of the Yucatan Peninsula, there are many shallow lagoons bordered by mangroves. Our study area was located adjacent to the northern coast of the state of Quintana Roo, Mexico, among a group of cays called 'Cayos-Contoy'. The experimental stations were located off the eastern coast of 'Cayo Alcatraz' $\left(21^{\circ} 28^{\prime} 1^{\prime \prime} \mathrm{N}, 86^{\circ} 53^{\prime} 9^{\prime \prime} \mathrm{W}_{i}\right.$ Fig. 1).

Mini-casitas similar to those described by Eggleston et al. (1990) were used, consisting of a concrete roof on a PVC frame $(130 \times 80 \mathrm{~cm})$ but the opening height was increased to $3.8 \mathrm{~cm}$. The study area has been described by Salgado-Peña (1995) and Sosa-Cordero et al. (in press). It was concluded that this is a Panulirus argus nursery ground from ecological observations on percent cover of macrophytobenthos (e.g. seagrass, red and green algae), occurrence of sponges, and annual frequency-size distribution of lobsters. In addition, seagrass Thalassia testudinum shoot density (Dennison 1990) and organic matter content (Dean 1974) were measured at each station during the present study.

Experimental stations. Five stations were selected as having the necessary differences in habitat structure (Fig. 1). Station (Stn) 1 was located on an unvegetated patch of reef (approx. $20 \mathrm{~m}$ radius) with an average depth of $4 \mathrm{~m}$. It was surrounded by a mixture of seagrass Thalassia testudinum and algal mat. The sediment was composed of a thin layer of medium and fine

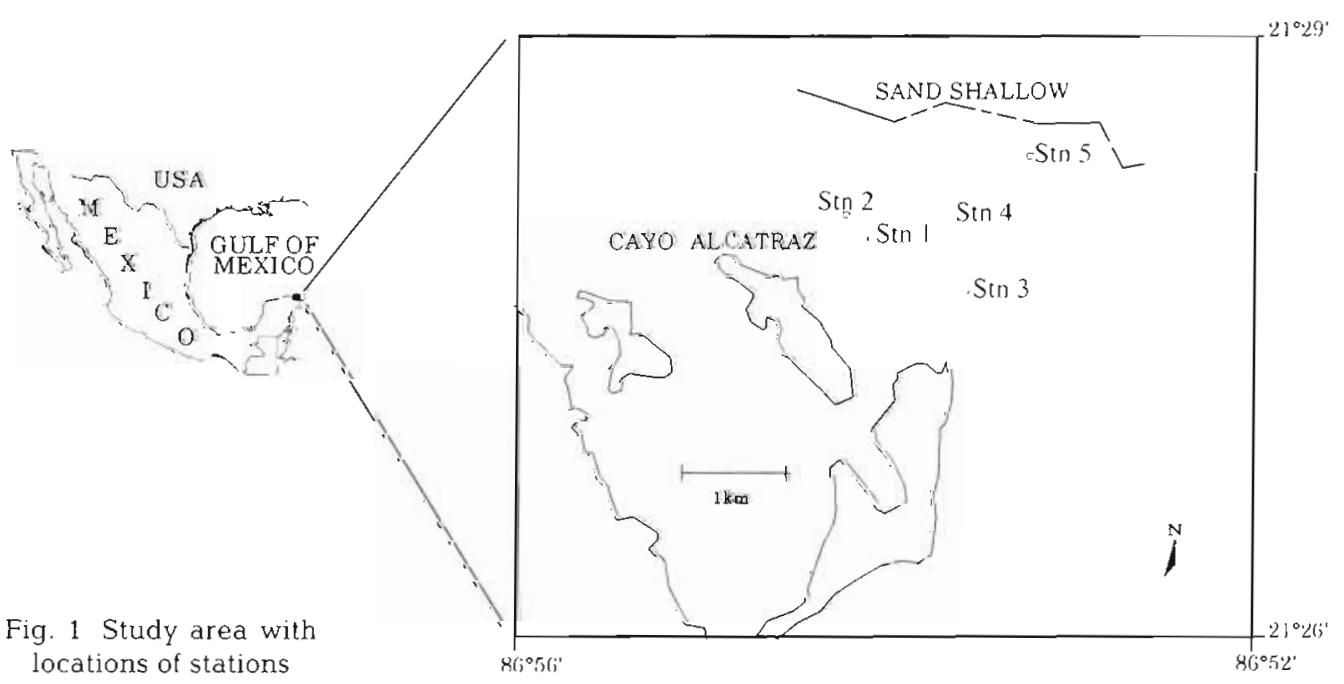


sand, accounting for consistently turbid water throughout the sampling period. Several species of hard corals were present, varying in height from approximately 10 to $70 \mathrm{~cm}$, including Siderastrea sp., Porites sp. and Diploria sp., the latter being the most conspicuous. Stn 2 had ecological characteristics similar to Stn 1 with respect to both the benthic substrata and surrounding vegetation. However, the hard corals were reduced in size and abundance, and the depth averaged $3.5 \mathrm{~m}$. Stns 3 and 4 were in seagrass meadows interspersed with algal mats of predominantly Caulerpa prolifera, Penicillus sp. and Halimeda sp. Stns 3 and 4 also had high seagrass shoot densities (means \pm 1 SE were $866.7 \pm 66.7$ and $900.0 \pm 251.7$ blades $\mathrm{m}^{-2}$ ) with depths of 1.5 and $3.5 \mathrm{~m}$, respectively. Stn 5 was the furthest from the eastern Cayo Alcatraz shoreline. It was located at a depth of $4.5 \mathrm{~m}$ with low to moderate seagrass density $\left(533.3 \pm 66.7\right.$ blades $\left.\mathrm{m}^{-2}\right)$ and several species of macroalgae also present, including Udotea sp., C. prolifera, Penicillus sp. and Halimeda sp. Stn 5 was subject to higher wave exposure than the other stations. Sponges occurred only at Stns 3 and 4 , and to a lesser extent at Stn 5.

Four mini-casitas were placed in every station in a square layout, $5 \mathrm{~m}$ apart from one another, giving 5 experimental stations with a total of $(4 \times 5=) 20$ casitas The mini-casita stations were checked by SCUBA every 23 d, on average, from November 1993 to October 1994 . This average sampling periodicity resulted in 2 sampling dates for March (the 8th and 26th). Lobsters were caught using hand nets after carefully tipping the casitas on their side. Lobsters were removed from every station, measured (mm carapace length, CL) and released approximately 2 to $5 \mathrm{~km}$ away. Early juvenile lobsters were classified according to the distinct ontogenetic groups described by Smith \& Herrnkind (1992): algal (5-15 mm CL), transitional (16-25 mm CL), and post-algal (26-35 mm CL). Late juveniles and subadults were divided into the classes: $36-45 \mathrm{~mm}$, 46-55 $\mathrm{mm}, 56-65 \mathrm{~mm}$, and $>65 \mathrm{~mm} \mathrm{CL}$, as used by other researchers (Eggleston et al. 1992). Other relevant biological variables such as lobster sex, number of potential predators and other large animals present were also recorded

The statistical analysis involved 1 -way classification analysis of variance (ANOVA) with habitat (experimental stations) as the independent factor and ungrouped ln-transformed size of lobster as the response variable. We tested whether the recruitment to each station was independent of the lobster size group, using the G-test of independence (Sokal \& Rohlf 1981). In addition, multiple regression analysis (Sokal \& Rohlf 1981) was used to determine whether the number of lobster per station and mean size of lobsters per station could be predicted using predator abundance per station, station type (dummy variable) and time of sampling. Correlations between pairs of regressor variables were examined. Plots of residuals from the multiple regression models were checked visually to detect departures from normality, outliers and homocedasticity.

\section{RESULTS}

\section{Analysis of frequencies}

Lobster population size structure

A total of 549 juvenile lobsters, 306 (55.8\%) males and $243(44.2 \%)$ females, were caught between November 1993 and October 1994. Minimum and maximum lobster sizes were 11.7 and $68.4 \mathrm{~mm} \mathrm{CL}$ respectively (Fig. 2). The mean size of the total sample was $29.9 \pm 0.44 \mathrm{~mm}$ CL (mean $\pm 1 \mathrm{SE}$ ), which corresponds to the juvenile post-algal stage. Size varied significantly ( $\alpha=0.05)$ among stations (1-way ANOVA, $F=64.851, \mathrm{df}=544, \mathrm{p}<0.001)$. Tukey's a posteriori mean comparison test $(\alpha=0.05)$ indicated a significant difference in lobster size for Stns 1 and 2 compared to Stns 3, 4, and 5; i.e. larger mean sizes (>45 $\mathrm{mm} \mathrm{CL}$ ) were recorded in patch reef habitats compared to those found in vegetated habitats. Another significant size difference was also found between Stns 3 and 4 (Fig. 3).

\section{Lobster abundance and recruitment}

Juvenile lobsters gradually colonized the minicasitas after their deployment in October 1993. The

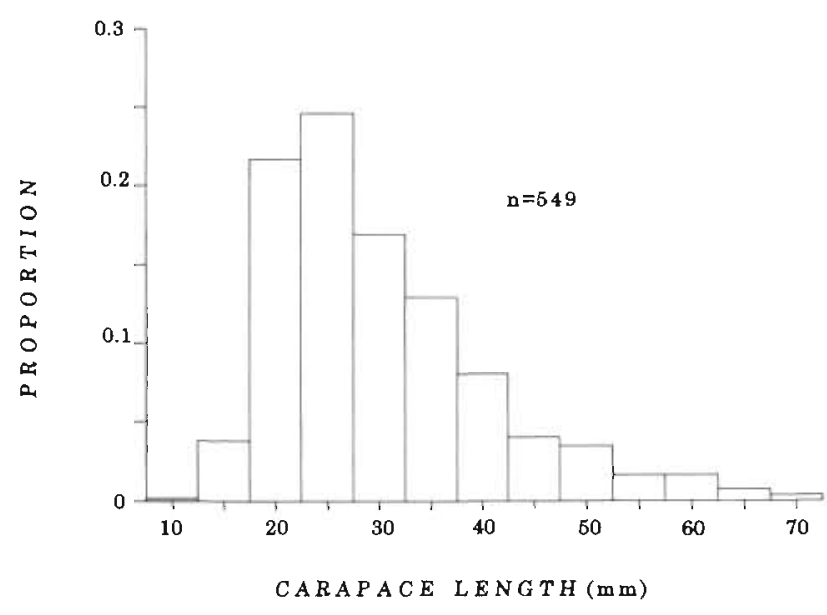

Fig. 2. Panulirus argus. Size frequency distribution of lobsters harbored by mini-casitas at Cayos-Contoy 


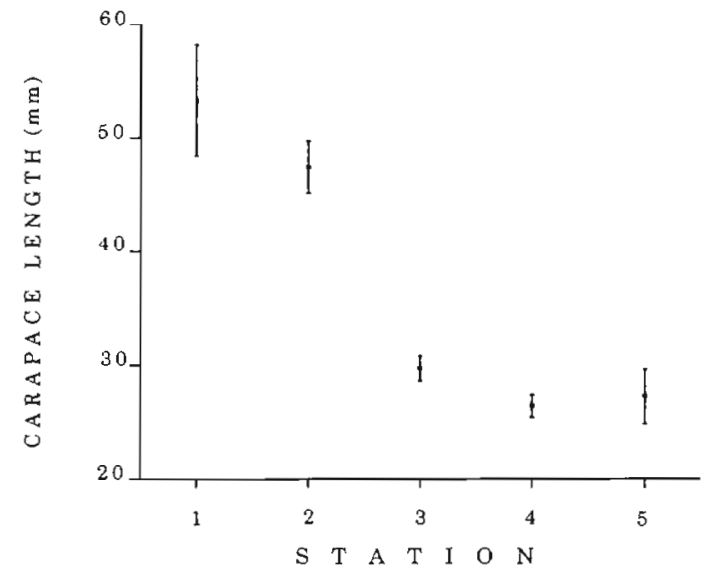

Fig. 3. Panulirus argus. Mean size ( $\pm 1 \mathrm{SE})$ of spiny lobsters at stations

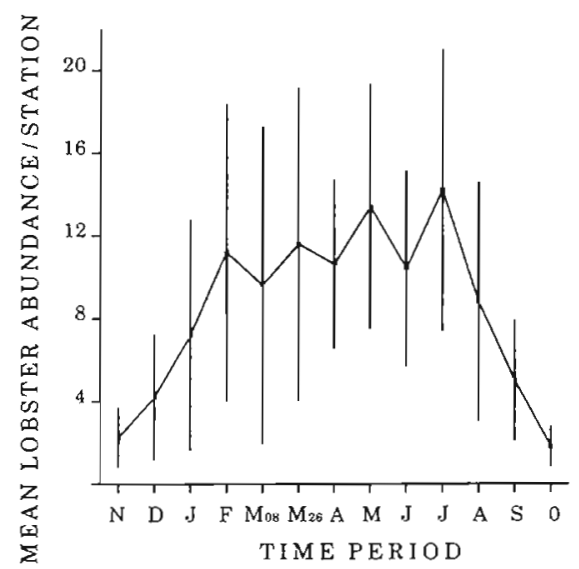

Fig. 4. Panulirus argus. Overall mean lobster abundance $( \pm 1$ SE) over time (March had 2 sampling dates, the 8 th and 26th)

intra-annual pattern of overall lobster abundance showed minima during October and November (1.8 and 2.5 lobsters per station) and the peaks during May and July (13.4 and 14.2 lobsters per station) (Fig. 4). Daily overall recruitment rates (i.e. the number of lobsters settled at the 5 stations $\mathrm{d}^{-1}$ ) ranged from 0.24 (October) to 3.22 (late March) (Table 1).

All stations except Stn 1 were consistently inhabited by juveniles most of the time (Table 1). However, differences in lobster abundance between stations were evident. Stns 3 and 4 were colonized by the highest number of early and late juveniles, with 198 (36.1\%) and $253(46.1 \%$ ) respectively; Stns 2 and 5 had intermediate values, while Stn 1 showed the lowest value (Table 2). The maximum abundance of juveniles per station, 41 lobster per station, was recorded on March 26 at Stn 4 (Table 1). The maximum carrying capacity of mini-casitas, 33 lobster per mini-casita, was registered in July at Stn 3.
Table 1 Panulirus arqus. Lobster abundance and overall recruitment rate over time (March had 2 sampling dates, the 8 th and 26th\}. nd: no data

\begin{tabular}{|lrrrrrc|}
\hline $\begin{array}{l}\text { Time } \\
\text { period }\end{array}$ & 1 & 2 & 3 & 4 & 5 & $\begin{array}{c}\text { Station } \\
\text { rate (lobster d }{ }^{-1} \text { ) }\end{array}$ \\
\hline Nov & 0 & 3 & 0 & 6 & nd & 0.33 \\
Dec & 0 & 4 & 0 & 16 & 1 & 0.91 \\
Jan & 0 & 1 & 1 & 29 & 5 & 1.06 \\
Feb $_{\text {Mar }_{08}}$ & 0 & 1 & 39 & 10 & 6 & 1.70 \\
Mar $_{26}$ & 0 & 0 & 5 & 40 & 3 & 2.29 \\
Apr & 0 & 15 & 9 & 41 & 7 & 3.22 \\
May & 0 & 7 & 26 & 29 & 5 & 1.56 \\
Jun & 0 & 10 & 20 & 22 & 0 & 2.31 \\
Jul & 0 & 5 & 36 & 24 & 6 & 1.86 \\
Aug & 0 & 0 & 30 & 12 & 2 & 2.96 \\
Sep & 5 & 0 & 16 & 1 & 3 & 1.19 \\
Oct & 3 & 1 & 5 & 0 & 0 & 0.24 \\
& & & & & & \\
\hline
\end{tabular}

Mini-casita occupancy varied among the lobster size groups (Table 2). Of the 549 lobsters caught, only 125 $(22.8 \%)$ were late juveniles and subadults, while 424 $(77.2 \%)$ were early juveniles, i.e. a high proportion of early juveniles occupied the mini-casitas, which is a life stage difficult to sample in the field. Transitional and post-algal stages accounted for 41.1 and $34.6 \%$ of the total sample respectively. The algal stage accounted for only $1.4 \%$. There was a significant association between lobster size groups and habitat types ( $G$-test with William's correction, $G=160.2, \mathrm{p}<0.001$ ). The vegetated habitats (Stns 3,4, and 5) were preferred mostly by early juveniles (Table 2), whereas late juveniles and subadults tended to occupy unvegetated patch reefs habitats (Stns 1 and 2).

\section{Macrofauna and predators}

A total of 1839 organisms associated with the minicasitas were recorded throughout the study period. Of this, only $29.8 \%$ were juvenile and subadult lobsters, while the remaining were potential predators (37.2\%) and other sheltering macrofauna (32.9\%). Potentia] predators of Panulirus argus seen during the surveys belonged to 3 taxa: Crustacea, Mollusca, and Teleostei (Table 3). Remains of brachyuran crabs (Xanthidae) and lobsters ( $P$. argus) were found in the stomach contents of Batrachoides mangle and Diplectrum formosum respectively.

Predator abundance was computed for every sampling date as the number of predators per station. The results of multiple regression analysis showed that no combination of regressor variables proved useful in predicting the number of lobsters per station at Cayos Contoy. However, the mean size of lobsters varied sig- 
Table 2. Panulirus argus. Total number of lobsters recruited to each station by

\begin{tabular}{|c|c|c|c|c|c|c|c|c|}
\hline \multirow[t]{3}{*}{ Stn } & \multicolumn{7}{|c|}{ Lobster size groups $(\mathrm{mm} \mathrm{CL})$} & \multirow[t]{3}{*}{ Total } \\
\hline & \multicolumn{3}{|c|}{ Early juveniles } & \multicolumn{4}{|c|}{ Late juveniles and subadults } & \\
\hline & $5-15$ & $16-25$ & $26-35$ & $36-45$ & $46-55$ & $56-65$ & $>65$ & \\
\hline 1 & 0 & 0 & 0 & 0 & 3 & 4 & 1 & 8 \\
\hline 2 & 0 & 2 & 6 & 13 & 17 & 8 & 2 & 48 \\
\hline 3 & 3 & 72 & 77 & 35 & 8 & 3 & 0 & 198 \\
\hline 4 & 3 & 131 & 94 & 23 & 2 & 0 & 0 & 253 \\
\hline 5 & 2 & 21 & 13 & 3 & 3 & 0 & 0 & 42 \\
\hline Total & 8 & 226 & 190 & 74 & 33 & 15 & 3 & 549 \\
\hline
\end{tabular}

Table 3. Potential predators of Panulirus argus sighted during mini-casitas surveys. 'First specific report of Octopus maya. Potential predators reported previously by: ' Randall (1983); ${ }^{2}$ Eggleston et al. (1990); ${ }^{3}$ Eggleston et al. (1992); ${ }^{4}$ Smith \& Herrnkind (1992); ${ }^{5}$ Mintz et al. (1994)

\begin{tabular}{|c|c|c|}
\hline Family & Species & $\begin{array}{l}\text { No. of org. } \\
\text { observed } \\
\text { per family }\end{array}$ \\
\hline \multicolumn{3}{|c|}{ Crustacea } \\
\hline \multicolumn{3}{|c|}{ Mollusca } \\
\hline Octopodidae & Octopus maya. & 34 \\
\hline \multicolumn{3}{|c|}{$\begin{array}{c}\text { Teleostei } \\
\text { Tell }\end{array}$} \\
\hline Batrachoididea & Toadfish Batrachoides mangle' & 139 \\
\hline Labridae & Slippery dick Halichoeres bivittatus ${ }^{4}$ & 6 \\
\hline Lutjanidae & $\begin{array}{l}\text { Schoolmaster snapper Lutjanus apodos }{ }^{2,3} \\
\text { Lane snapper Lutjanus synagris } 5 \\
\text { Gray snapper Lutjanus griseus } 2,3.4\end{array}$ & 87 \\
\hline Pomadasyidae & Grunt Haemulon spp. ${ }^{4}$ & 244 \\
\hline Serranidae & $\begin{array}{l}\text { Red grouper Epinephelus morio } \\
\text { Sand perch Diplectrum formosum }\end{array}$ & 135 \\
\hline Diodontidae & Porcupinefish Diodon spp. & 6 \\
\hline Muraenidae & $\begin{array}{l}\text { Green moray eel Gymnothorax funebris } \\
\text { Spotted moray eel Gymnothorax moringa }\end{array}$ & 8 \\
\hline
\end{tabular}

Table 4. Results of the multiple regression for mean size of lobsters per station. Independent variables were: station (Stn), number of predators (Pred) and Time. $\mathrm{R}^{2}$ is adjusted for model df. $\cdots p<0.001$

\begin{tabular}{|lrcccccc|}
\hline Source & df & SS & MS & $F$ & $R^{2}$ adj. & Variable & $\begin{array}{c}\text { Standardized } \\
\text { coefficients }\end{array}$ \\
\hline Model & 3 & 2.269 & 0.768 & $16.88 \cdots$ & 0.52 & Stn & -0.689 \\
Error & 40 & 1.792 & 0.045 & & & Pred & -0.120 \\
Total & 43 & 4.060 & & & & Time & 0.389 \\
\hline
\end{tabular}
defined size groups

lobsters was negatively correlated with the number of predators and station, and positively correlated with the time of sampling. The standardized coefficients (Table 4) show that station, followed by time and predators, was the most influential variable of the model. No pairs of regressor variables were significantly correlated (Time-Pred $r=-11.83, p=0.44$; TimeStn $r=-0.108, p=0.49 ;$ Pred-Stn $r=$ $0.150, p=0.33$ ). Ln-transformed mean size of lobsters and number of predators station ${ }^{-1}$ were normally distributed [Kolmorgorov-Smirnov tests $(\mathrm{K}-\mathrm{S}) ; D_{\max }=0.107, \mathrm{p}=0.70 ; D_{\max }=$ $0.107, \mathrm{p}=0.46$, respectively].

\section{DISCUSSION}

The juvenile lobster size structure harbored by mini-casitas at CayosContoy emphasized the importance of the study area as a nursery habitat for Panulirus argus. The averaged size of juveniles collected varied between stations and appeared to be related to habitat type. Lobsters were larger in unvegetated patch reefs than in vegetated habitats. The spatial distribution of $P$. argus often has been reported in the literature as habitat-related, with larger lobsters usually found in deeper water and reef habitats, and/or with a gradual shoreward decrease in size (Lyons et al. 1981, Gregory et al. 1982, Gregory \& Labisky 1986, LozanoAlvarez et al. 1991, 1994). Our study found that small-scale habitat changes were also significant.

Juvenile lobsters recruited preferentially to the 2 most vegetated habitats (Stns 3 and 4), with seagrass meadows, algal mats and a greater occurrence of sponges. Survival experiments with Panulirus argus have reported that seagrass meadows pronificantly as a function of the number of predators per station, station, and time (Table 4). The resulting equation was:

$$
y=3.753-0.003(\text { Pred) }-0.148(\mathrm{Stn})+0.032 \text { (Time) }
$$

where $y=$ mean lobster size (ln-transformed) and Pred $=$ number of predators station ${ }^{-1}$. The mean size of vide protection from predation (Eggleston et al. 1990). In addition, seagrass meadows are very productive (Orth 1986) and considered to be important spiny lobster feeding areas (Kanciruk 1980, Lipcius \& Herrnkind 1982, Eggleston et al. 1990. Herrera et al. 1991, Briones et al. 1994). Thus, it is very likely that food abundance for juveniles was also higher at Stns 3 and 
4 than at the remaining stations. Herrnkind \& Butler (1986) suggest that habitat selection by $P$. argus juveniles seems to be influenced by food availability. However, evidence gathered from several studies demonstrates that habitat use by lobsters may result from a complex interaction of factors, such as the protective value of a scaled shelter (Eggleston et al. 1990) and from the attraction of chemical stimuli from food, predators and conspecifics (Zimmer-Faust et al. 1985, Zimmer-Faust \& Spanier 1987, Wahle 1992, Boudreau et al. 1993, Childress \& Herrnkind 1994, Spanier 1994).

Stns 1 and 2 were located on sandy reefs with hard corals but lacked the suitable seagrass and algal mat habitats for postlarvae settlement and subsequent juvenile growth. Thus, we suggest that a lack of critical resources (Bohnsack et al. 1991), such as food and appropriate substratum, was responsible for the low abundance of juveniles registered at these stations. In addition, experiments on Panulirus argus survival report higher mortality rates in the open, unvegetated areas (Herrnkind \& Butler 1986, Eggleston et al. 1990, Smith \& Herrnkind 1992). We suggest that the low abundance of lobsters registered at Stn 5, which has low to moderate seagrass density, may also be a result of strong wave action.

Mini-casitas were frequently shared by lobsters of differing size groups; nevertheless, there is clear evidence that habitat type is very important in determining whether early juveniles or late juveniles and subadults are attracted to the mini-casitas. The removal of all lobsters from mini-casitas on every sampling date resulted in reoccupation mostly by size-specific juveniles to habitat type. Zimmer-Faust \& Spanier (1987) reported a significant size stratification in den occupancy by Panulirus interruptus, suggesting a lack of randomness in individual residency. We suggest that the ontogenetic change in sheltering behaviour and sociality reported for spiny lobsters (Zimmer-Faust \& Spanier 1987, Smith \& Herrnkind 1992) should be taken into account when studying juvenile spiny lobster ecology.

In the present study the abundance of the algal stage 5-15 mm CL was consistently low even at the most vegetated stations. This may be because our study was not focused on the post-larval stage, i.e. we did not use the more specific post-larval artificial collector (see Whitam et al. 1968, Briones \& Gutiérrez 1991, Cruz et al. 1991). Our results, therefore, did not evaluate the effect of post-larval settlement rates and its effect on juvenile abundance at Cayos-Contoy.

Casitas accupancy was dominated by transitional (16-25 mm CL) and post-algal ( $26-35 \mathrm{~mm}$ CL) juvenile stages with 41.1 and $34.6 \%$ respectively. Caddy \& Stamatopoulos (1990) suggested that artificial habitats could be used to determine the relative availability of crevices of different sizes in natural environments. In order to detect a population bottleneck effect, these authors proposed identifying the highest percentage of artificial shelter occupancy by a given size class of lobsters. Hence, based on the observation that the highest percentage of mini-casitas occupancy is by the transitional size group, we suggest that natural shelter of appropriate size was possibly a limiting factor for this juvenile stage. This could indicate a juvenile lobster population bottleneck (Sosa-Cordero et al. in press). In support of this are the benthic substrata characteristics observed in the study area. Sosa-Cordero et al. (in press) report that hard bottom and patch reef cover was quite scarce in the study area, comprising only $0.2 \%$; in contrast, the vegetated bottom was highly abundant, with $79.7 \%$ of cover.

Considering that in our study most of the lobsters were $\leq 35 \mathrm{~mm} \mathrm{CL}$, the lack of a significant (quantitative) relationship between the number of juvenile lobsters per station and the set of predictor variables employed agrees with similar findings reported for juvenile Panulirus argus in Florida Bay (Field \& Butler 1994). We suggest that a failure to predict the number of juvenile lobsters within a given area also reflects the high temporal and spatial stochasticity associated with the post-settlement process in this species. Only longterm monitoring studies are likely to reveal consistent patterns and whether or not any key environmental factor is associated with them.

Acknowledgements. We thank the fishermen from the Sociedad Cooperativa 'Isla Blanca' at Isla Mujeres, Quintana Roo, for their logistic support. D. Ceballos, J. Salgado-Peña, and E. I. Núnez-Leal provided valuable field assistance. Mr Alfredo Martin-Sierra (fisherman) provided invaluable support throughout the study, especially during the cold-front season. We also acknowledge the comments and the suggestions of 3 anonymous referees. Dr R. K. Zimmer-Faust provided relevant published literature. Ms Mary L. Whitlow greatly improved our English grammar. This work was funded by the Aquaculture, Ministry of Fisheries (SEPESCA). and the Centro de Investigaciones de Quintana Roo (CIQRO). SEPESCA authorized the 'Permisos de Pesca de Fomento' nos. 1002 and 1006.

\section{LITERATURE CITED}

Alfonso I, Frías MP (1991) Distribución y abundancia de larvas de la langosta Panulirus argus en aguas alrededor de Cuba. Rev Invest Mar 12:5-19

Bohnsack JA, Johnson DL, Ambrose RF (1991) Ecology of artificial reef habitats and fishes. In: Seaman W Jr. Sprague LM (eds) Artificial habitats for marine and freshwater fisheries. Academic Press, San Diego, p 61-107

Boudreau B, Bourget E, Simard Y (1993) Effect of age, injury, and predator odors on settlement and shelter selection by lobster Homarus americanus postlarvae. Mar Ecol Prog Ser 93:119-129

Briones P, Gutiérrez D (1991) Variaciones en el patrón de reclutamiento de postlarvas de la langosta Panulirus argus 
en Bahia de la Ascensión, México. Rev Invest Mar 12: $45-56$

Briones P, Lozano E, Eggleston DB (1994) The use of artificial shelters (casitas) in research and harvesting of Caribbean spiny lobsters in Mexico. In: Phillips BF, Cobb JS, Kittaka $\mathrm{J}$ (eds) Spiny lobster management. Fishing News Books, Oxford, p 340-361

Caddy JF (1986) Modelling stock-recruitment processes in crustacea: some practical and theoretical perspectives. Can J Fish Aquat Sci 43:2330-2344

Caddy JF, Stamatopoulos C (1990) Mapping growth and mortality rates of crevice-dwelling organisms onto a perforated surface: the relevance of 'cover' to the carrying capacity of natural and artificial habitats. Estuar Coast Shelf Sci 31:87-106

Childress MJ, Herrnkind WF (1994) The behavior of juvenile Caribbean spiny lobster in Florida Bay: seasonality, ontogeny and sociality. Bull Mar Sci 54:819-827

Cruz R, Brito R, Díaz E, Lalana R (1986) Ecología de la langosta (Panulirus argus) al SE de Isla de la Juventud. I Colonización de arrecifes artificiales. Rev Invest Mar 7:3-17

Cruz R, de León ME, Díaz E, Brito R, Puga R (1991) Reclutamiento de puerulos de langosta (Panulirus argus) a la plataforma cubana. Rev Invest Mar 12:66-75

Cruz R, Phillips BF (1994) The artificial shelters (pesqueros) used for the spiny lobster (Panulirus argus) fisheries in Cuba. In: Phillips BF, Cobb JS, Kittaka J (eds) Spiny lobster management. Fishing News Books, Oxford, • p 323-339

Davis GE (1971) Aggregations of spiny sea urchins, Diadema antillarum, as shelters for young spiny lobsters, Panulirus argus. Trans Am Fish Soc 100:586-587

Davis GE (1985) Artificial structure to mitigate marina construction impacts on spiny lobster, Panulirus argus. Bull Mar Sci 37:151-156

Dean WE (1974) Determination of carbonate and organic matter in calcareus sediment and sedimentary rocks by loss on ignition: comparison with other methods. J Sediment Petrol 44(1):242-248

de León ME, Cruz R, Díaz E, Brito R, Puga R, del Castillo J (1991) Distribución y estacionalidad de juveniles de Panulirus argus en la plataforma cubana. Rev Invest Mar 12: $117-124$

Dennison WC (1990) Shoot density. In: Phillips RC, McRoy P (eds) Seagrass research methods. UNESCO monographs in oceanographic methodology 9, Paris, p 61-63

Eggleston DB, Lipcius RN (1992) Shelter selection by spiny lobster under variable predator risk, social conditions and shelter size. Ecology 73:992-1011

Eggleston DB, Lipcius RN, Miller DL (1992) Artificial shelters and survival of juvenile spiny lobster Panulirus argus: spatial, habitat, and lobster size effects. Fish Bull US 90: $691-702$

Eggleston DB, Lipcius RN, Miller DL, Coba-Cetina L (1990) Shelter scaling regulates survival of juvenile Caribbean spiny lobster Panulirus argus. Mar Ecol Prog Ser 62:70-88

Field JM, Butler JM IV (1994) The influence of temperature, salinity and postlarval transport on the distribution of juvenile spiny lobsters Panulirus argus (Latreille, 1804), in Florida Bay. Crustaceana 67:26-45

Forcucci D, Butler MJ IV, Hunt JH (1994) Population dynamics of juvenile Caribbean spiny lobster, Panulirus argus, in Florida Bay, Florida. Bull Mar Sci 54:805-818

Gregory DR Jr, Labisky RF (1986) Movements of the spiny lobster Panulirus argus in south Florida. Can J Fish Aquat Sci 43:2228-2234

Gregory DR Jr, Labisky RF, Combs CL (1982) Reproductive dynamics of the spiny lobster Panulirus argus in South Florida. Trans Am Fish Soc 111:575-584

Herrera A, Ibarzábal D, Foyo J, Espinosa J (1991) Alimentación natural de la langosta Panulirus argus en la región de los Indios (Palataforma $\mathrm{SW}$ de Cuba) y su relación con el bentos. Rev Invest Mar 12:172-182

Herrnkind WF, Butler MJ IV (1986) Factors regulating postlarval settlement and juvenile microhabitat use by spiny lobsters Panulirus argus. Mar Ecol Prog Ser 34:23-30

Herrnkind WF, Butler MJ IV (1994) Settlement of spiny lobster, Panulirus argus (Latreille, 1804), in Florida: pattern without predictability? Crustaceana 67:46-64

Herrnkind WF, Jernakoff P. Butler MJ IV (1994) Puerulus and post-puerulus ecology. In: Phillips BF, Cobb JS, Kittaka J (eds) Spiny lobster management. Fishing News Books, Blackwell, London, p 213-229

Hixon MA, Beets JP (1989) Shelter characteristics and Caribbean fish assemblages: experiments with artificial reefs. Bull Mar Sci 44:666-680

Hixon MA, Beets JP (1994) Predation, prey refuges and the structure of coral-reef fish assemblages. Ecol Monogr 63: $77-101$

Johnson DL, Beaumier BA, Lynch WE Jr (1988) Selection of habitat structure interstice size by bluegills and largemouth bass in ponds. Trans Am Fish Soc 117:171-179

Kanciruk P (1980) Ecology of juvenile and adult Palinuridae (spiny lobsters). In: Cobb JS, Phillips BF (eds) The biology and management of lobsters, Vol 2. Academic Press, New York, p 59-96

Lipcius RN, Herrnkind WF (1982) Molt cycle alterations in behavior, feeding and diel rhytms of a decapod crustacean, the spiny lobster Panulirus argus. Mar Biol 68: $241-252$

Lozano-Alvarez E, Briones-Fourzán P, Negrete-Soto F (1994) An evaluation of concrete block structures as shelter for juvenile Caribbean spiny lobsters Panulirus argus. Bull Mar Sci 55:351-362

Lozano-Alvarez E, Briones-Fourzán P, Phillips BF (1991) Fishery characteristics, growth and movements of the spiny lobster Panulirus argus in Bahia de la Ascension, Mexico. Fish Bull US 89:79-89

Lyons WG, Barber DG, Foster SM, Kennedy FS Jr, Milano GA (1981) The spiny lobster, Panulirus argus, in the middle and upper Florida Keys: population structure, seasonal dynamics, and reproduction. Fla Mar Res Publ 38:1-38

Marx JM. Herrnkind WF (1985) Macroalgae (Rhodophyta: Laurencia spp.) as habitat for young juvenile spiny lobsters, Panulirus argus. Bull Mar Sci 36:423-431

Marx JM, Herrnkind WF (1986) Species profiles: life histories and environmental requirements of coastal fishes and invertebrates (south Florida) - spiny lobster. US Fish Wild Serv Biol Rep 82(11.61). US Army Corps of Engineers, TREL-82-4

Miller DL (1982) Mexico's Caribbean fisheries: recent changes and current issues. PhD thesis, University of Wisconsin, Milwaukee

Mintz JD, Lipcius RN, Eggleston DB, Seebo MS (1994) Survival of juvenile Caribbean spiny lobster: effects of shelter size, geographic location and conspecific abundance. Mar Ecol Prog Ser 112:255-266

Morse DR, Lawton JH, Dodson MM, Williamson MH (1985) Fractal dimension of vegetation and the distribution of arthropod body lengths. Nature (Lond) 314:731-733

Norman P, Yamakawa H, Yoshimura T (1994) Habitat selection, growth rate and density of juvenile Panulirus japonicus (Von Siebold, 1824) (Decapoda, Palinuridae) at banda, Chiba Prefecture, Japan. Crustaceana 66:366-383 
Orth RJ (1986) Potential values of seagrass meadows as critical nursery areas in the Indian Ocean, an evaluation method for associated faunal communities. In: Thompston MF, Sarojini R, Nagabhushanam R (eds) Indian Oceanbiology of benthic marine organisms. Oxford IBH Publishing Company, New Delhi, p 167-176

Randall JE (1983) Caribbean reef fishes. TFH Publications Inc Ltd, Honolulu

Salgado-Peña JF (1995) Caracterización de las comunidades bentónicas de un área de pesca de langosta (Panulirus argus, Latreille 1804) en los Cayos-Contoy, Q. Roo, México. Tesis Profesional. Facultad de Ciencias Marinas, Universidad Autónoma de Baja California. Ensenada, México

Smith KN, Herrnkind WF (1992) Predation on early juvenile spiny lobsters Panulirus argus (Latreille): influence of size and shelter. J Exp Mar Biol Ecol 157:3-18

Sokal RR, Rohlf FJ (1981) Biometry. WH Freeman and Co, San Francisco

Sosa-Cordero E, Arce AM, Aguilar-Dávila W, RamírezGonzález A (in press) Artificial shelters for spiny lobster (Panulirus argus Latreille): an evaluation of occupancy under different benthic habitats. J Exp Mar Biol Ecol

Editorial responsibility: Otto Kinne (Editor),

Oldendorf/Luhe, Germany
Spanier E (1994) What are the characteristics of a good artificial reef for lobsters? Crustaceana 67:173-186

Spanier E, Tom M, Pisanthy S, Almog G (1988) Seasonality and shelter selection by the slipper lobster Scyllarides latus in the southeastern Mediterranean. Mar Ecol Prog Ser 42:247-255

Spanier E, Zimmer-Faust RK (1988) Some physical properties of shelter that influence den preference in spiny lobsters. J Exp Mar Biol Ecol 121:137-149

Wahle RA (1992) Roundtable on lobster ecology seeks more communication between behaviorist and population modellers. Lobster Newsl 5:2-3

Witham R, Ingle RM, Joyce EA Jr (1968) Physiological and ecological studies of Panulirus argus from the St. Lucie estuary. Fla Bd Conserv Mar Res Lab Tech Ser 53:1-31

Zimmer-Faust RK, Spanier E (1987) Gregariousness and sociality in spiny lobsters: implications for den habitation. J Exp Mar Biol Ecol 105:57-71

Zimmer-Faust RK, Tyre JE, Case JF (1985) Chemical attraction causing aggregation in the spiny lobster Panulirus interruptus (Randall), and its probable ecological significance. Biol Bull (Woods Hole) 169:106-118

Submitted: March 26, 1997; Accepted: July 9, 1997 Proofs received from author(s): October 13, 1997 